Digital Press Life Sciences

Viability and Antifungal Activity of Lactobacillus plantarum HL-15 Oven Dried Culture during Storage

Tri Marwati, Titiek F. Djaafar, Evelyn E. Setiawan, Tyas Utami and Endang S. Rahayu

10th Asian Conference of Lactic Acid Bacteria

I Nengah Sujaya, Endang S. Rahayu, Tyas Utami (eds) 


\title{
Viability and Antifungal Activity of Lactobacillus plantarum HL-15 Oven Dried Culture during Storage
}

\author{
Tri Marwati1 ${ }^{*}$, Titiek F. Djaafar ${ }^{1}$, Evelyn E. Setiawan ${ }^{2}$, Tyas Utami² and Endang S. Rahayu ${ }^{2}$ \\ ${ }^{1}$ Postharvest Department, Assessment Institute for Agricultural Technology Yogyakarta, Indonesia \\ 2 Faculty of Agricultural Technology, Gadjah Mada University, Yogyakarta, Indonesia \\ *e-mail: watipasca2@gmail.com
}

\begin{abstract}
Lactobacillus plantarum HL-15 has the ability to inhibit the growth of mycotoxin-producing fungi. To support the application of the use of these cultures, a study was carried out aimed at producing $\operatorname{dry} L$. plantarum HL-15 and observing its stability during storage. Production of dry culture begins with fermentation of L. plantarum HL-15 then centrifugation is carried out to obtain pellets. Pellets were mixed with fillers (rice flour or tapioca) with a ratio of pellets: fillers $(10 \%)=1: 1(\mathrm{v} / \mathrm{v})$ and then dried. The drying machine used is an oven with a temperature of $45^{\circ} \mathrm{C}$ for 20 hours. The dry culture was packaged in aluminum foil and sealed and then stored at $4^{\circ} \mathrm{C}$. The result showed that viable cells of oven-dried $L$. plantarum HL-15 with rice filler was $<4 \log$ CFU/g and oven-dried culture with tapioca filler was 8,94 log CFU/g. The viability of oven-dried L. plantarum HL-15 decreased during two-month storage.
\end{abstract}

\section{Keywords}

viability, antifungal, oven-dried culture, lactobacillus plantarum HL 15

\section{Introduction}

In dried cocoa beans are often found myotoxin-producing fungi, namely A. niger, A. flavus, A. fumigatus, Fusarium sp, Penicillium sp, Trichoderma sp., Mucor sp. and Verticillium sp [1]. The presence of the Aspergillus family (A. niger, A. flavus, A. tamari, A. glaucus) Penicillium and Mucor are likely to cause mycotoxins in cocoa beans and hydrolyze fats into short-chain fatty acids [2]. In addition, the presence of fungi in cocoa beans has an impact on the appearance of unpleasant taste due to the lipolytic enzyme activity [3]. Aspergillus has the potential to produce Ochratoxin A (OTA), one of the mycotoxins with carcinogenic and immunotoxic effects. Due to health effects, the European Union (EU) has set a maximum OTA limit on some foods, this law will affect international trade in some food commodities [4].

Biological fungus growth control can prevent mycotoxin contamination in food chain production. Lactic acid bacteria in the fermentation process of cocoa beans have the potential to inhibit the growth of mycotoxin-producing fungi [5]. Leuconostoc paramesenteroides BK 15 and BK 24 and Pediococcus spp. BK 14 has the ability to inhibit the growth of A. flavus, A. niger, A. ochraceus, and Penicillium spp. [6] Lactobacillus fermentum F1L-6an which was able to inhibit the growth of A. niger, A. fumigatus and Mucor spp ] [7]. Lactobacillus plantarum B4496, L. brevis 207 and Lactobacillus sanfranciscensis BB12 showed extensive antifungal activity in vitro against the fungus producing ochratoxin A. carbonarius, A. nigerand A. ochraceus [8]. Leuconostoc mesenteroides (L16B, B28C), L. plantarum (B40B, B88C), L. fermentum (B88C, B40B), L. paramesenteroides L16A and L. casei (L16A, B28C) produce compounds that are antifungal against A. flavus, A. ochraceus and Penicillium spp. [9].

Damage caused by fungal is a major concern for the food industry. A promising solution to reducing fungal growth is the use of lactic acid bacteria. Lactic acid bacteria produce antifungal compounds that can interfere with the growth of pathogenic microorganisms in the form of organic acids (lactic acid, acetic acid, and propionic acid), cyclic peptides and acetic acid [10,11]. The inhibition of organic acids on 
microorganisms is associated with a decrease in $\mathrm{pH}$ value. The undissociated acid molecule can diffuse into the cell. The resulting organic acid may inhibit the germination of conidia in the fungus [12]. Lactobacillus plantarum produces a metabolite with a low molecular mass that can inhibit the P. avenaceum fungus [13]. Lactobacillus reuteri produces a secondary metabolite called reuterin which can inhibit fungi. A reuterin is a highly reactive group of aldehydes that can react with the thiol and protein groups causing oxidative stress in the cells so that cells will be inhibited [11].

Liquid starter cultures have a limited shelf life and are bulky. To extend shelf life, culture can be preserved in freeze and dry form. However, during freezing, lactic acid bacteria can lose their viability and ability to produce acids [14]. In addition, frozen culture requires sub-zero temperatures for transportation and storage. Dry culture is a good form of preserves for culture stock [15]. From several drying methods (spray drying, oven drying, drum drying, vacuum drying, fluidized bed drying, and water drying), spray drying has been developed as a culture preservation technique. The spray dryer has high speed and continuous production therefore it is very useful for drying large numbers of starter cultures [16] Removing water using spray drying can reduce costs by up to six times per kg of water compared to those using freeze-drying [17].

Fillers are needed in the production of dry culture. The addition of fillers aims to support the growth of target microbes and maintain desired microbial populations over a period of time [18]. Filler must be able to act as a protector for lactic acid bacteria from the effect of heat during drying, safe to consume and cheap price so that final product price becomes economical. Filler for the production of dried cultures can be gelatin, gum Arabic, alginate and starch [19]. Starch is a raw material filler that is cheap, available abundant, renewable, biodegradable and nontoxic [20]. Rice flour and tapioca are potentially used as filler because the price is economical, and the availability is abundant. The application of rice flour and tapioca on the production of dried culture is also done quite a lot and give good results [21,22].

Lactobacillus plantarum HL15 isolated from fermented cocoa beans in Yogyakarta Indonesia has the ability to inhibit the growth of Aspergillus niger YAC-9 which produces mycotoxins [23]. Therefore, this study aims to produce L. plantarum HL-15 dry and observe its stability during storage. This research will study the effect of adding rice flour and tapioca fillers on the viability of L. plantarum HL-15 culture after drying using a spray and oven dryer, and the effect of storage conditions on viability, moisture content and antifungal activity of L. plantarum HL-15

\section{Methods}

\subsection{Preparation of culture}

The culture used for dry culture production in this research was L. plantarum HL15 isolated from fermented cocoa beans in Yogyakarta Indonesia [23]. L plantarum HL 15 was grown in MRS broth (Oxoid) media and incubated at $37^{\circ} \mathrm{C}$ for 24 hours. The culture is stored in a cold room before use. For antifungal tests, Aspergillus niger YAC-9 was used as a fungus producing mycotoxins.

\subsection{Oven drying}

Pellet L. plantarum HL15 added with a $10 \%$ solution of filler solution (rice flour or tapioca) with a ratio of pellet and filler solution is $1: 1(\mathrm{v} / \mathrm{v})$. Then the culture mixture is stirred and dried using an oven at $45^{\circ} \mathrm{C}$ for 20 hours. The L. plantarum HL15 dry starter is vacuum-packed in a polyethylene bag, and stored at $4^{\circ}$ C. Viable cells of Dry starter were counted after centrifugation and oven drying when storage reached $4^{\circ} \mathrm{C}$. During storage, an analysis of water content and antifungal activity of the dry culture of L. plantarum HL15 was conducted monthly. 


\subsection{Enumeration of L. plantarum HL15}

The enumeration of L. plantarum HL15 was carried out using the dilution and plating method, using MRS agar media. Plates were incubated at $37^{\circ} \mathrm{C}$ for 48 hours. The results of enumeration are expressed as colony forming units (CFU) per ml of suspension or per gram of solids.

\subsection{Determination of water content}

The water content of oven-dried of $L$. plantarum HL15 culture was determined by thermogravimetry

\subsection{Antifungal assay of $L$. plantarum HL15}

The mycotoxin-producing fungus used in this study was Aspergillus niger YAC-9. Assay for the antifungal activity of L. plantarum HL15 was carried out using the overlay method [24]. L. plantarum HL15 inoculated in MRS agar media, then overlayed with PDA media containing Aspergillus niger YAC-9, then incubated at $27^{\circ} \mathrm{C}$ for 3 days. Antifungal activity was determined by calculating the fungal biomass through the width of the fungi diameter. The smallest fungi biomass shows the largest antifungal activity of L. plantarum HL15.

\section{Results and Discussion}

\subsection{The viability of $L$. plantarum HL-15 during biomass production, after centrifugation and after oven drying}

A very important initial process in the preparation of a starter is the production of biomass. In this process, L. plantarum HL-15 grown on a suitable medium and controlled to produce cells in large quantities. In this study selected MRS media, because the media contains peptone, yeast extract and glucose needed bacteria to grow properly. The MRS medium is widely used for Lactobacillus because the composition and concentration of the medium are suitable for the growth of the bacteria and easy in harvesting the cells [25]. The initial cell count of L. plantarum HL-15 for biomass production was 9,98 log CFU/ml and 9,98 log $\mathrm{CFU} / \mathrm{ml}$. After harvesting the cell increased by about $3.3 \log$ to $13,28 \log \mathrm{CFU} / 2000 \mathrm{ml}$ and $3.3 \log$ to 13,28 logs CFU/2000 ml (Table 1).

Table 1 The viability of L. plantarum HL-15 during biomass production, after centrifugation and after oven drying

\begin{tabular}{|c|c|c|c|c|}
\hline Filler & $\begin{array}{c}\text { al cell number (log } \\
\mathrm{CFU} / \mathrm{ml})\end{array}$ & $\begin{array}{r}\text { I number after biomass } \\
\text { production (log } \\
\text { CFU } / 2000 \mathrm{ml})\end{array}$ & $\begin{array}{l}\text { nber after centrifugation } \\
(\log \mathrm{CFU} / 50 \mathrm{ml})\end{array}$ & $\begin{array}{c}\text { imber after oven drying } \\
\text { (log CFU/gram) }\end{array}$ \\
\hline :ice flour & $9,98 \pm 0,05$ & $13,28 \pm 0,05$ & $11,67 \pm 0,05$ & $<4 \pm 0,00$ \\
\hline Tapioca & $9,98 \pm 0,05$ & $13,28 \pm 0,05$ & $11,67 \pm 0,05$ & $8,94 \pm 0,04$ \\
\hline
\end{tabular}

Table 1 shows that there is a decrease in cell number after drying with oven dryer either on rice flour or tapioca filler with a decreasing value of $>7,67 \log$ and 2,73 logs. According to Blaine [26], the cause of loss viability during drying is the protein denaturation by the carbonyl group which reacts with the amino group of the protein cell.

During the drying process of L. plantarum HL-15, there was a decrease in water content causing cell instability that can decrease cell viability and activity. The filler provides a protective effect on the cell because it creates a thick wall filler that can trap cells within the microparticles and can stabilize cellular structures (especially on DNA or RNA, proteins, and enzymes) during drying [27]. 
From the data obtained, tapioca is better than on rice flour in maintaining the cell during drying. This is presumably because the carbohydrate content of tapioca $(86.9 \%)$ is greater than rice flour $(80 \%)$. The addition of a carbohydrate-binding agent may prevent cell death during drying, the higher the carbohydrate content in the carrier, the higher the cell protection [28]. This is supported by the results of the research by Arisanti [21] using tapioca ingredient in dry inoculum Lactobacillus plantarum Argentoratensis NBRC 106468 has cell viability of $2.5 \times 109$ CFU / g and is able to maintain higher cell viability during 10 weeks storage by $1,5 \times 108 \mathrm{CFU} / \mathrm{g}$ compared to $1.6 \times 107 \mathrm{CFU} / \mathrm{g}$ rice flour.

\subsection{The viability and water content of oven-dried L. plantarum HL-15 during storage at $4^{\circ} \mathrm{C}$}

During 2 months of storage, there is a decrease in the number of cells up to 1-2 log cycles per month in oven-dried L. plantarum HL-15 with tapioca filler. While oven-dried L. plantarum HL-15 with rice flour filler was not detected since after the drying process up to storage for 2 months (Table 2). The decline is thought to be caused by the packaging not being done vacuum, so there is still air (oxygen) trapped in the packaging. Air can cause death in cells because the air (oxygen) can oxidize the lipids that are on the cell membranes that cause damage to all parts of the cell [15].

Water content is one of the determinants of the stability of dry cultures. Water content in dry inoculum should not be more than 11\%, for a microbiological reason [29]. After drying, the water content of the material decreases when the cell in its growth requires free water as a reactant in various biochemical reactions. During storage, the entire biochemical and enzymatic reactions of the cell remain even slow. This limited condition causes its microbial activity to decline until the cell eventually dies.

Table 2 The viability and water content of oven-dried L. plantarum HL-15 during storage at $4^{\circ} \mathrm{C}$

\begin{tabular}{lcccc}
\hline time (month) & \multicolumn{2}{c}{ Viability (CFU/g) } & \multicolumn{2}{c}{ Water content (\%) } \\
\cline { 2 - 5 } & $\begin{array}{c}\text { Iried culture using rice } \\
\text { flour filler }\end{array}$ & $\begin{array}{c}\text { lried culture using } \\
\text { tapioca filler }\end{array}$ & $\begin{array}{c}\text { lried culture using } \\
\text { rice flour filler }\end{array}$ & $\begin{array}{c}\text { dried culture using } \\
\text { tapioca filler }\end{array}$ \\
\hline 0 & $<4 \pm 0,00$ & $8,94 \pm 0,04$ & $8,08 \pm 0,06$ & $9,21 \pm 0,07$ \\
1 & $<3 \pm 0,00$ & $7,35 \pm 0,04$ & $8,82 \pm 0,05$ & $9,60 \pm 0,09$ \\
2 & $<2 \pm 0,00$ & $6,12 \pm 0,04$ & $9,20 \pm 0,32$ & $10,28 \pm 0,12$ \\
\hline
\end{tabular}

The water content of spray-dried L. plantarum HL-15 with tapioca filler is 9,21\% while spray-dried $L$. plantarum HL-15 with tapioca filler has water content 8,08\%. Furthermore, during the storage of 1 up to 2-month, the water content of both spray-dried culture is increased (Table 2). According to Blaine [26], there are three factors that influence the stability of dry culture during storage namely air around storage, temperature and humidity. Increasing the water content during storage is thought to be caused by the packaging is not vacuum. That is, there is air trapped in the packaging, causing an increase in water content during storage. Dry culture in powder form is hygroscopic, therefore high relative humidity will cause the water content level to increase until equilibrium.

Oxygen, moisture content, and light had a negative effect on the stability of dry culture. Therefore, it is important to store dry cultures in appropriate packers and suitable storage conditions [30]. The packing material selected in this study is aluminum foil because the aluminum foil is inert, reflective, non-absorbent, which is an effective barrier for water and air, and can form oxide layers when exposed by air to avoid further oxidation [31]. 


\subsection{The antifungal activity of oven-dried L. plantarum HL-15 during storage at $4^{\circ} \mathrm{C}$}

Antifungal tests were carried out on oven-dried L. plantarum HL-15 with tapioca filler having viability above $10^{8} \mathrm{CFU} / \mathrm{g}$. From the results of the oven-dried L. plantarum HL-15 inhibition test against the growth of $A$. niger YAC 9 fungus, it is known that oven-dried L. plantarum HL-15 inhibitory activity is not significant (Fig. 1)

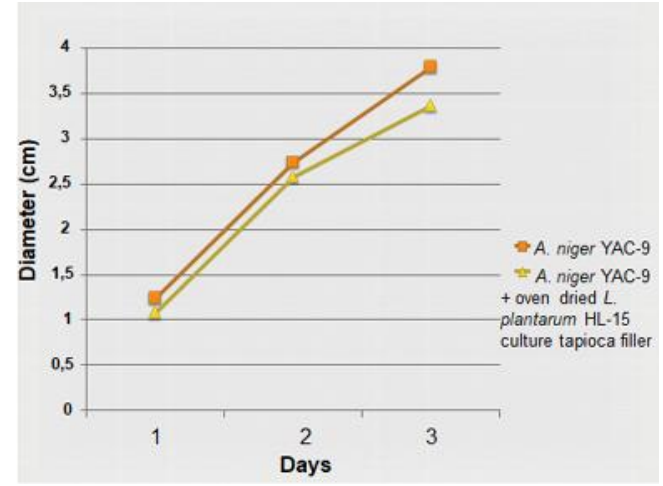

Fig 1. Growth of A. niger YAC 9 in 3 days incubation

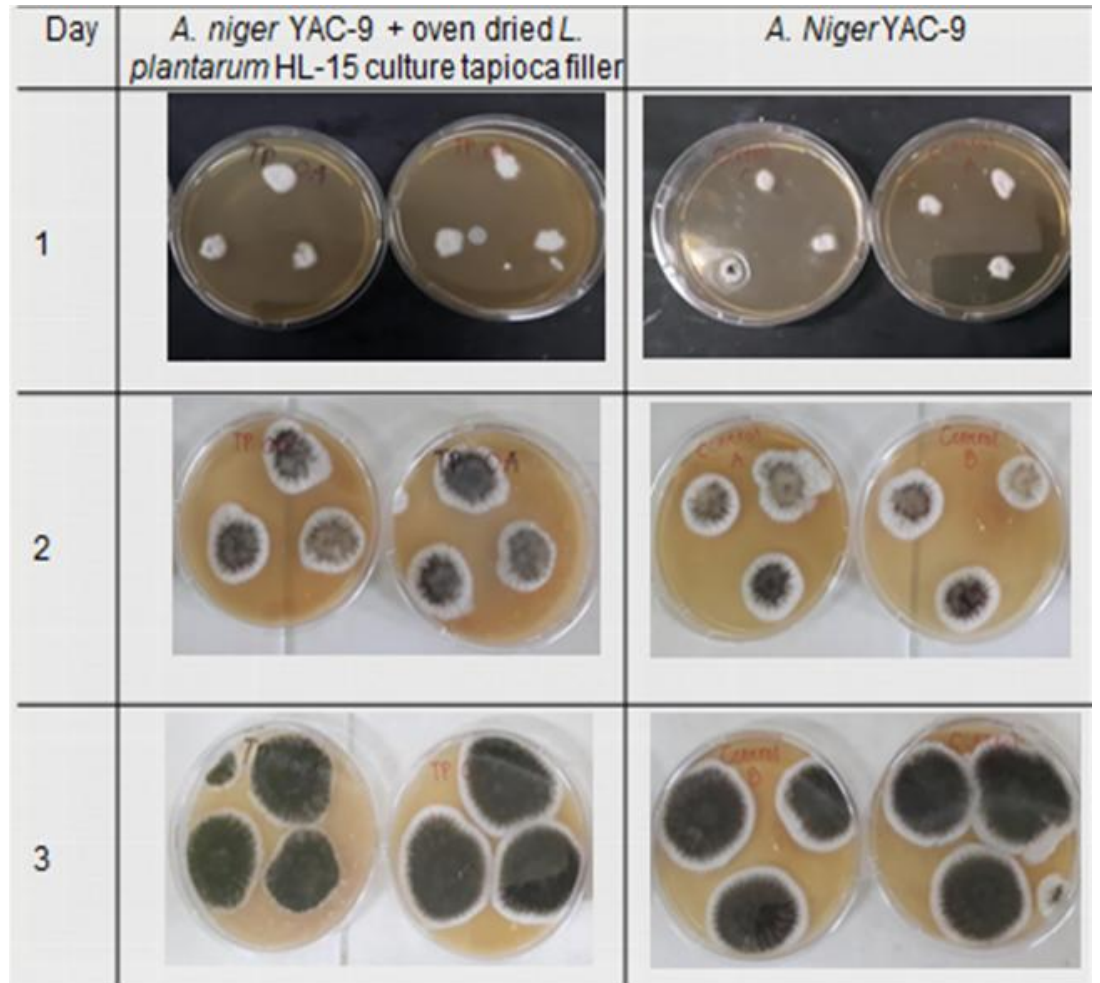

Fig 2 The growth of A. niger YAC 9 treated with oven-dried L. plantarum tapioca filler and A. niger YAC 9 control

\section{Conclusion}

Viable cells of oven-dried L. plantarum HL-15 with rice filler was $<4 \log$ CFU/g and oven-dried culture with tapioca filler was 8,94 log CFU/g. The viability of oven-dried L. plantarum HL-15 decreased during a twomonth storage.

Acknowledgment The research was financially supported by the Indonesian Agency for Agricultural Research and Development (IAARD) through Collaborative Research, Assessment, and Development of Strategic Agriculture Project 


\section{References}

1. Asrul: Populasi jamur mikotoksigenik dan kandungan aflatoksin pada beberapa contoh biji kakao (Theobroma cacao L) asal Sulawesi Tengah. Agroland, 16 :258-267 (2009)

2. Christensen, C. M.: Field and storage fungi. In: L. R. Beuchat (ed.), Food and beverage mycology, 2nd ed. AVI/Van Nostrand Reinhold, pp 211-232. New York, N.Y. (1987)

3. Lund, B.M.: The Microbiological Safety and Quality of Food. Volume II. Aspen Publisher Inc, Maryland (2000)

4. Nugroho, A.D, Setyabudi, F.M.C.S., salleh, B., Rahayu, E.S.: Ochratoxigenic black Aspergilli isolated from dried agricultural products in Yogyakarta, Indonesia. Journal of Food Science and Engineering, 3:472-480 (2013)

5. Sardjono: Occurence and Detoxification of Micotoxins in Food. Agritech, 23(2): 97-102 (2003)

6. Suwarsono, Susijahadi: Eksplorasi agens antikapang dari bakteri asaam laktat pada fermentasi kakao dan potensinya untuk meningkatkan kualitas komoditi kakao ekspor. Laporan Penelitian Hibah Bersaing Perguruan Tinggi tahun 2007-2008 (2007)

7. Fitriana, N.I.: Isolasi dan Identifikasi Bakteri Asam Laktat Indigenous dengan Potensi Antikapang dari Fermentasi Kakao di PTPN XII Kebun Banjarsari. Jember, Technical Report (2012)

8. Ngang, J.J.E., Yadang, G., Kamdem, S.I.S., Kouebou, C.P., Fanche S.A.Y., Kougan, D.L.T., Tsoungui, A., Etoa, F.X.: Antifungal properties of selected lactic acid bacteria and application in the biological control of ochratoxin A producing fungi during cocoa fermentation. Journal Biocontrol Science and Technology, 25(3): 245-259 (2015). doi:10.1080/09583157.2014.969195

9. Putri, B.C.P.: Identifikasi bakteri asam laktat sebagai anti kapang dari fermentasi kakao di gunung kidul yogyakarta. Skripsi. Jurusan Teknologi Hasil Pertanian, Fakultas Teknologi Pertanian, Universitas Jember (2015)

10. Ross, R.P., Morgan, S., Hill, C.: Preservation and fermentation: past, present and future. International Journal of Food Microbiology, 79(1-2): 3-16 (2002). doi:10.1016/S0168-1605(02)00174-5

11. Crowley, S., Mahony, J., Sinderen, D.V.: Current perspectives on antifungal lactic acid bacteria as natural bio-preservatives. Trends in Food and Science Technology, 33(2): 93-109 (2013). doi:10.1016/j.tifs.2013.07.004

12. Muhialdin, B.J., Hassan, Z., Sadon, S.K., Zulkifli, N.A., Azfar, A.A.: Effect of ph and heat treatment on antifungal activity of Lactobacillus fermentum TE007, Lactobacillus pentosus G004 and Pediococcus pentosaceus TE010. Innovative Romanian Food Biotechnology, 8: 41-53 (2011)

13. Niku-Paavola, M.L., Laitila, A., Mattila-Sandholm, T., Haikara, A.: New types of antimicrobial compounds produced by Lactobacillus plantarum. Journal of Applied Microbiology, 86: 29-35 (1990).

14. To B.C.S., Etzel M.R. 1997. Spray drying, freeze drying, or freezing of three different lactic acid bacteria species, Journal of Food Science, 62(3): 576-585 (1997). doi:10.1111/j.1365-2621.1997.tb04434.x

15. Santivarangkna, C., Kulozik, U., Foerst, P.: Inactivation mechanism of lactic acid starter cultures preserved by drying processes. Journal of Applied Microbiology, 105(1): 1-13 (2008). doi:10.1111/j.13652672.2008.03744.x

16. Peighambardoust, S.H., Tafti, A.G., Hesari, J.: Application of spray drying for preservation of lactic acid starter cultures: A review. Trends in Food Science \& Technology, 22(5): 215-224 (2011). doi:10.1016/j.tifs.2011.01.009

17. Desmond C., Stanton C., Fitzgerald G.F., Collins K., Ross R.P.: Environmental adaptation of probiotic Lactobacilli towards improvement of performance during spray drying. International Dairy Journal, $12(2-$ 3):183-190 (2001). doi:10.1016/s0958-6946(02)00040-7

18. Stephens, J.H.G., Rask, H.M.: Inoculant production and formulation. Field Crops Research, 65(2-3): 249258 (2000). doi:10.1016/S0378-4290(99)00090-8

19. Lian, W.C., Hung-Chi H., Chen-Chun C.: Survival of bifidobacteria after spray-drying. International Journal of Food Microbiology, 74: 79-86 (2002). doi:10.1016/s0168-1605(01)00733-4

20. Winarti C., Sunarti T.C., Mangunwidjaja D., Richana N.: Potensi dan aplikasi pati termodifikasi sebagai bahan aktif bahan matriks enkapsulasi bahan bioaktif. Buletin Teknologi Pasca Pertanian, 9(2): 83-94 (2013)

21. Arisanti, D.: Viabilitas Bakteri Asam Laktat Selama Penyiapan dan Penyimpanan Ragi Mocaf serta Aplikasinya Pada Fermentasi Ubi Kayu Segar. Diss. Universitas Gadjah Mada, Yogyakarta (2012)

22. Nurfiana, D. A.: Pengembangan Inokulum Kering Lactobacillus plantarum HL 15 Dengan Metode Pengering Oven untuk Fermentasi Biji Kakao. Skripsi. Fakultas Teknologi Pertanian. Universitas Gadjah Mada, Yogyakarta (2016) 
23. Khusna, R. N.: Isolasi Dan Identifikasi Bakteri Asam Laktat Dari Biji Kakao Terfermentasi Dan Potensinya Sebagai Antijamur. Skripsi Fakultas Teknologi Pertanian. Universitas Gadjah Mada, Yogyakarta (2016)

24. Hassan, Y.I., Bullerman, L.B.: Antifungal activity of Lactobacillus paracasei ssp. tolerans isolated from a sourdough bread culture. International Journal of Food Microbiology 121(1): 112-115 (2008). doi:10.1016/j.ijfoodmicro.2007.11.038

25. Charteris, W.P., Kelly, P.M., Morelli, L., Collins, J.K.: Selective Detection, enumeration and identification of potentially probiotic Lactobacillus and Bifidobacterium species in mixed bacterial populations. International Journal of Food Microbiology, 35(1):1-27 (1997). doi:10.1016/s0168-1605(96)01222-6

26. Blaine, J. W.: Preparation and Preservation of Lactic Acid Inokulum Culture Concentrates. Oregon, Oregon State University (1972)

27. Lapsiri, W. Bhandari, B. Wanchaitanawong, P.: Viability of Lactobacillus plantarum TISTR 2075 in different protectants during spray drying and storage. Drying Technology, 30(13): 1407-1412 (2012). doi:10.1080/07373937.2012.684226

28. Linders, L.J.M., Jong, G.I.W., Meerdink, G., Riet, K.V.: Carbohydrates and the dehydration inactivation of Lactobacillus plantarum: The role of moisture distribution and water activity. Journal of Food Engineering, 31(2): 237-250 (1997). doi:10.1016/s0260-8774(96)00077-5

29. Leja, K., Bia, W., \& Jankowski, T.: Production of dry Lactobacillus rhamnosus GG preparations by spr drying and lyophilization in aqueous two-phase system. Acta Sci Pol Technol Aliment, 8(4): 39-49 (2009)

30. Utami, T., Kasmiati, Harmayani, E., Rahayu, E.S.: Survival of Lactobacillus plantarum Dad 13 during spray drying and its application for yoghurt fermentation. International Research Journal of Biological Sciences, $5(2): 16-22(2016)$

31. Kerry,J.: Aluminium Foil Packaging. Packaging Technology, 163-177 doi:10.1533/9780857095701 